\title{
Distribution of Dinophysis species and their association with lipophilic phycotoxins in plankton from the Argentine Sea
}

\author{
Elena Fabro a,b,*, Gastón O. Almandoz ${ }^{\mathrm{a}, \mathrm{b}}$, Martha Ferrario ${ }^{\mathrm{a}, \mathrm{b}}$, Urban Tillmann ${ }^{\mathrm{c}}$, \\ Allan Cembella ${ }^{\mathrm{c}}$, Bernd $\mathrm{Krock}^{\mathrm{c}}$ \\ a División Ficología, Facultad de Ciencias Naturales y Museo, Universidad Nacional de La Plata, Paseo del Bosque s/n (B1900FWA), La Plata, Argentina \\ ${ }^{\mathrm{b}}$ Consejo Nacional de Investigaciones Científicas y Técnicas (CONICET), Av. Rivadavia 1917, 1033 Buenos Aires, Argentina \\ ' Alfred-Wegener-Institut, Helmholtz Zentrum für Polar- und Meeresforschung, Am Handelshafen 12, 27570 Bremerhaven, Germany
}

\section{A R T I C L E IN F O}

\section{Article history:}

Received 5 April 2016

Received in revised form 12 September 2016 Accepted 13 September 2016

Available online

\section{Keywords:}

Diarrheic shellfish toxins

Lipophilic toxins

LC-MS/MS

Dinophysis

D. norvegica

Argentine Sea

\begin{abstract}
A B S T R A C T
Dinophysis is a cosmopolitan genus of marine dinoflagellates, considered as the major proximal source of diarrheic shellfish toxins and the only producer of pectenotoxins (PTX). From three oceanographic expeditions carried out during autumn, spring and late summer along the Argentine Sea $\left(\sim 38-56^{\circ} S\right)$, lipophilic phycotoxins were determined by liquid chromatography coupled to tandem mass spectrometry (LC-MS/MS) in size-fractionated plankton samples. Lipophilic toxin profiles were associated with species composition by microscopic analyses of toxigenic phytoplankton. Pectenotoxin2 and PTX-11 were frequently found together with the presence of Dinophysis acuminata and Dinophysis tripos. By contrast, okadaic acid was rarely detected and only in trace concentrations, and dinophysistoxins were not found. The clear predominance of PTX over other lipophilic toxins in Dinophysis species from the Argentine Sea is in accordance with previous results obtained from north Patagonian Gulfs of the Argentine Sea, and from coastal waters of New Zealand, Chile, Denmark and United States. Dinophysis caudata was rarely found and it was confined to the north of the sampling area. Because of low cell densities, neither D. caudata nor Dinophysis norvegica could be biogeographically related to lipophilic toxins in this study. Nevertheless, the current identification of $D$. norvegica in the southern Argentine Sea is the first record for the southwestern Atlantic Ocean. Given the typical toxigenicity of this species on a global scale, this represents an important finding for future surveillance of plankton-toxin associations.
\end{abstract}

(c) 2016 Elsevier B.V. All rights reserved.

\section{Introduction}

Marine dinoflagellates of the genus Dinophysis include more than 120 phototrophic and heterotrophic species in marine waters over the entire world (Jensen and Daugbjerg, 2009). This cosmopolitan genus includes species with a wide geographical distribution, such as Dinophysis acuminata, which occurs within a wide range of temperature regimes (Kamiyama et al., 2010), whereas others, such as Dinophysis norvegica and Dinophysis tripos, apparently with more restricted environmental tolerances, mainly occur in boreal and tropical-temperate waters, respectively (Reguera et al., 2012).

\footnotetext{
* Corresponding author at: División Ficología, Facultad de Ciencias Naturales y Museo, Universidad Nacional de La Plata, Paseo del Bosque s/n (B1900FWA), La Plata, Argentina. Fax: +54 2214257527.

E-mail address: fabroelena@yahoo.com.ar (E. Fabro).
}

Among all members of the genus Dinophysis, 10 species have been found to produce lipophilic polyether phycotoxins, known collectively as diarrheic shellfish toxins (DST), including okadaic acid (OA) and dinophysistoxin (DTX) derivatives. Seven of these analogs have been implicated as causative agents of diarrheic shellfish poisoning (DSP) (Reguera and Pizarro, 2008), an important human illness syndrome linked to consumption of contaminated shellfish. The first clinical report of diarrheic syndrome related to consumption of shellfish came from the Netherlands (Korringa and Roskam, 1961), but the causative organism was not determined until the 1980s, when this new toxic syndrome was described as DSP (Yasumoto et al., 1978) and Dinophysis fortii identified as the toxic agent (Yasumoto et al., 1980). Subsequent studies confirmed OA and DTX as the main compounds responsible for DSP (Murata et al., 1982).

In addition to toxigenic Dinophysis species, the heterotrophic dinophysoid Phalacroma rotundatum has been included in the list of DSP toxin-containing species (Reguera et al., 2014 and 
references therein), but the production of such toxins by this species has not been confirmed. González-Gil et al. (2011) suggested that $P$. rotundatum may act as a vector of toxins taken up from ciliate prey that have previously fed on co-occurring toxic Dinophysis spp. In contrast, the confirmed toxigenic Dinophysis species all possess plastids and hence they are capable of performing photosynthesis. Moreover, toxin production has been clearly linked to photosynthesis (Kim et al., 2008). Hence the capacity for de novo DST production in heterotrophic species remains highly questionable, and it is more likely that heterotrophic dinoflagellates only accumulate toxins rather than produce them.

Certain members of the genus Dinophysis also produce pectenotoxins (PTX), a large family of lipophilic polyether toxins originally associated with the DSP toxin complex. The PTX analogs produced by Dinophysis may be modified by metabolic activity within shellfish; for example PTX-2 can be modified to the corresponding seco-acid PTX-2sa (Lee et al., 1989; Suzuki et al., 1998; Ciminiello et al., 2010). Toxicological studies indicate that PTX are not diarrheagenic after oral administration to laboratory rodents, and hence are not true DST, but PTX-1 is hepatotoxic albeit at high acute concentrations (Terao et al., 1986). The risk to human health regarding this group of toxins remains under toxicological discussion and review by regulatory authorities.

Historical records on the occurrence of Dinophysis in the Argentine Sea include a large contingent of around 30 species, with Dinophysis acuminata cited as the most common and widely distributed species (Balech, 1988). Among these species, D. acuminata, Dinophysis tripos, Dinophysis caudata and Dinophysis fortii are included in the IOC-UNESCO reference list of toxic microalgae (Zingone and Larsen, 2014) as putative or confirmed producers of DST. Nevertheless, in spite of the common presence of Dinophysis spp. in Argentine coastal waters, confirmed reports of DSP are rather exceptional. The first documented case of human intoxication by DSP in Argentina occurred in 1999 in Chubut Province in Patagonia and was linked to consumption of bivalve shellfish that had been harvested in the Gulf of San José and Nuevo Gulf $\left(\approx 42^{\circ} \mathrm{S}\right)$. This DSP event was related, however, to the presence of the benthic dinoflagellate Prorocentrum lima (Gayoso et al., 2002), which is also known to produce OA, DTX-1 and other variants (Quilliam and Ross, 1996).

More recently, a DSP outbreak was associated with the presence of Dinophysis acuminata and Dinophysis caudata on the northern coast of Buenos Aires Province (36.5-37 $\mathrm{S}$ ) in summer 2010, and during which both OA and DTX-1 were detected in mussels by liquid chromatography with fluorescence detection (LC-FD) (Sar et al., 2010, 2012). Later, positive mouse bioassays for DSP were recorded in mussels collected in the same area during January and November, 2012, and related circumstantially to the presence of $D$. acuminata and D. caudata, respectively (Sunesen et al., 2014). Recent monitoring programs in the gulfs of north Patagonia obtained positive mouse bioassays for DST related to the presence of D. tripos (Gracia Villalobos et al., 2015). In addition, PTX-2 has been detected off the coast of Buenos Aires Province (Montoya et al., 2013), in the Gulf of San Jorge (Krock et al., 2015), in shelf waters from $40^{\circ} \mathrm{S}$ to $46^{\circ} \mathrm{S}$ (Fabro et al., 2015) and in the Gulf of San José and Nuevo Gulf (Gracia Villalobos et al., 2015). Finally, OA and DTX-1 have been recently detected by liquid chromatography coupled with tandem mass spectrometry (LC-MS/MS) in shellfish collected in several coastal areas of Buenos Aires Province (Turner and Goya, 2015). The role of Dinophysis blooms in DSP events along the Argentine coast thus remains rather enigmatic and poorly defined, both with respect to associated species and known toxin composition.

Three oceanographic expeditions were conducted over an extended area $\left(\approx 38-56{ }^{\circ} \mathrm{S}\right)$ of the coastal Argentine Sea and adjacent shelf and slope waters and in different seasons (autumn, late summer and spring) with the purpose of determining the potential biogeographical linkages between toxic microalgae and their associated toxins. In the analysis presented here the distribution and abundance of Dinophysis spp. in the Argentinean Sea is described, and relationships between their occurrence and their respective lipophilic toxin composition are established.

\section{Material and methods}

\subsection{Field sampling protocols}

The continental shelf waters of the Argentine Sea were sampled during three oceanographic expeditions. Expedition 1 was conducted in autumn onboard the $R / V$ Puerto Deseado from March 30th to April 14th, 2012. A total of 47 stations were sampled between $\approx 38$ and $56^{\circ} \mathrm{S}$. The second expedition was carried out in late austral summer on the R/V Bernardo Houssay from March 11th to March 22 nd, 2013, with 24 sampling stations located between $\approx 39$ and $43^{\circ} \mathrm{S}$. This cruise was divided in two legs $\mathrm{K} 1$ and $\mathrm{K} 2$, which comprise 8 and 16 sampling stations, respectively. The third expedition was conducted in austral spring aboard the $R / V$ Puerto Deseado, from October 26 to November 09, 2013, with 47 sampling stations located between $\approx 40$ and $47^{\circ} \mathrm{S}$. The conductivity (salinity)/temperature/depth (CTD) data were available throughout all expeditions, except from leg $\mathrm{K} 2$ of Expedition 2, during which no CTD measurements were performed. During this leg, only surface water temperature was measured with a multiparameter probe TOA-DKK Model WQC.

Plankton samples were collected by vertical net tows through the upper $20 \mathrm{~m}$ of the water column with a $20 \mu \mathrm{m}$-mesh Nitex net of $60 \mathrm{~cm}$ diameter for both taxonomic and phycotoxin analysis. Each net haul concentrate was diluted up to $1 \mathrm{~L}$ with $0.2 \mu \mathrm{m}$ filtered seawater. An aliquot was fixed with acidic Lugol's iodine solution for species identification and enumeration. The rest was sequentially filtered through Nitex mesh of 200,50 and $20 \mu \mathrm{m}$ in PVC cylinders by gravity filtration and split into aliquots for toxin extraction. On Expedition 3, aliquots of each size-fraction were also taken for plankton analysis by microscopy. The total net sample was filtered through Nitex mesh of 200,50 and $20 \mu \mathrm{m}$ and resuspended in $40 \mathrm{~mL}$ of filtered seawater. During all three expeditions, Niskin bottle samples were also taken from 3 and $10 \mathrm{~m}$ depth and mixed in equal volume for determination of total plankton community composition and quantitative analyses.

\subsection{Phytoplankton analysis}

Cell densities of Dinophysis species in net tow concentrates was determined by counting $1 \mathrm{~mL}$ of acidic Lugol's iodine fixed samples in Sedgewick-Rafter chambers (LeGresley and McDermott, 2010) with an inverted microscope (Leica DMIL LED). Data recovered from cell counting of the net samples concentrates was used as semi-quantitative information to compare cell densities and toxin concentrations. Cell densities are expressed per net tow (cells NT ${ }^{-1}$ ), which corresponds to the total net harvest concentrate diluted up to $1 \mathrm{~L}$. In plankton cell counting from Expeditions 1 and 2, $1 \mathrm{~mL}$ of total net material was used for semi-quantitative calculations, so the limit of detection of the counting method was 1000 cells NT ${ }^{-1}$. During Expedition 3 the total net material $(1 \mathrm{~L})$ was filtered through three meshes (20, 50 and $200 \mu \mathrm{m})$ and re-suspended in $40 \mathrm{~mL}$ of filtered seawater, of which $1 \mathrm{~mL}$ from each fraction was counted for semi-quantitative estimations. In this case, the limit of detection was 40 cells $\mathrm{NT}^{-1}$.

Cell densities of Dinophysis species in plankton samples collected by Niskin bottles was determined according to the Utermöhl (1958) inverted microscope method. Subsamples 
$(50 \mathrm{~mL})$ from the Niskin bottles from fixed depths were left to settle for $24 \mathrm{~h}$ in a composite sedimentation chamber prior to counting. The limit of detection of this method was 20 cells $\mathrm{L}^{-1}$ for the three expeditions.

Further morphological examination of selected samples was conducted with a phase contrast/differential interference contrast optical microscope (Leica DM2500) equipped with a DFC420C camera, and under a scanning electron microscope (Jeol JSM-6360 LV SEM). For SEM analysis, samples were filtered onto $0.2 \mu \mathrm{m}$ polyamide filters and sputter-coated with Au-Pd.

\subsection{Toxin analysis}

Cell pellets from the plankton net tow size-fractions were collected by centrifugation $\left(3220 \times \mathrm{g}, 15 \mathrm{~min}\right.$ at $\left.4{ }^{\circ} \mathrm{C}\right)$, suspended in $500 \mu \mathrm{L}$ methanol, and subsequently homogenized with $0.9 \mathrm{~g}$ of lysing matrix $\mathrm{D}$ by reciprocal shaking at maximum speed $\left(6.5 \mathrm{~m} \mathrm{~s}^{-1}\right)$ for $45 \mathrm{~s}$ in a Bio101 FastPrep instrument (Thermo Savant, Illkirch, France). After homogenization, samples were centrifuged at $16,100 \times \mathrm{g}$ at $4{ }^{\circ} \mathrm{C}$ for $15 \mathrm{~min}$. The supernatant was transferred to a spin-filter $(0.45 \mu \mathrm{m}$ pore-size, Millipore Ultrafree, Eschborn, Germany) and centrifuged for $30 \mathrm{~s}$ at $800 \times \mathrm{g}$, followed by transfer to autosampler vials. Analysis of multiple lipophilic toxins was performed by liquid chromatography coupled to tandem mass spectrometry (LC-MS/MS), as described in Krock et al. (2008). Toxin concentrations are expressed as nanograms per net tow $\left(\mathrm{ng} \mathrm{NT}^{-1}\right)$.

\subsection{Toxin cell quotas}

Cell quotas of lipophilic phycotoxins (calculated as toxin content divided by the number of cells) were estimated from samples containing only one putatively toxigenic Dinophysis species or where a single toxigenic species represented $>90 \%$ of the cells of this genus. Following recommendations of the study of cell counting methods reported by ICES (2006), only those samples with cell abundances $>10,000$ cells $\mathrm{NT}^{-1}$ were considered for cell toxin quota estimates. PTX-2sa and isomers were excluded from the estimate of PTX-2 cell quotas. For samples collected during expeditions 1 (autumn) and 2 (late summer), Dinophysis acuminata and Dinophysis tripos cells were assigned to each size-fraction according to their cell dimensions.

\section{Results}

Microscopic examination of the field material from the three expeditions along the Argentine Sea revealed the presence of nine Dinophysis species, of which four are known to be toxigenic: Dinophysis acuminata, Dinophysis caudata, Dinophysis norvegica, and Dinophysis tripos (Fig. 1). As D. norvegica was found for the first time in South-Atlantic waters a description of the specimens from this area is provided.

Dinophysis norvegica cells were moderate in size, varying from 45 to $57 \mu \mathrm{m}$ in length. The characteristic cell shape was presented by Argentine field specimens, exhibiting greatest cell width just above the transverse mid-line of the cell body and with a convex dorsal outline and concave ventral side toward the antapex (Fig. 2). The large hypothecal plates showed a coarse texture and were heavily areolated, and in some cells they possessed small irregular antapical knobs (Fig. 2C). The left sulcal list ended at the beginning of the ventral concavity and presented three ribs, R2 closest to R1 (Fig. 2A), and R3 directed antapically (Fig. 2B). The right sulcal list was rather small and triangular in shape.

Other Dinophysis species, not known to be toxigenic, including Dinophysis truncata, Dinophysis operculata, Dinophysis cuneis, Dinophysis minuta and Dinophysis subcircularis were present at some stations during Expedition 1 and/or 3, but were detected only in net samples and never dominant. Distribution of these species is shown in Fig. 3. The heterotrophic dinophysoid species Phalacroma rotundatum was also found in low cell densities.

\subsection{Dinophysis acuminata distribution and related toxins}

On Expedition 1 (autumn), Dinophysis acuminata was found in $80 \%$ of net samples, from stations between 38 and $56^{\circ} \mathrm{S}$, representing an average of $88 \%$ of the toxigenic species of the genus. This species was present in $33 \%$ of Niskin bottle samples, exhibiting highest cell densities (100-160 cells $\mathrm{L}^{-1}$ ) in the southern Argentine Sea and within San Jorge Gulf (Fig. 4). Pectenotoxin-2 was detected in $63 \%$ of the net samples in the 20-50 $\mu \mathrm{m}$ size-fraction, with the highest concentrations in the southern Argentine Sea; the analog PTX-2sa represented on average $14 \%$ of the total PTX-2 group (Supplementary Table S1). Dinophysis acuminata was observed at all stations where PTX-2 was also found within the $20-50 \mu \mathrm{m}$ size-fraction (Fig. 5). The toxin quota estimated for $D$. acuminata varied from 0.2 to $15 \mathrm{pg} \mathrm{cell}^{-1}$ $(n=12)$, with maximum values found in the southern range of the sampling area (52-54 $\mathrm{S})$. Pectenotoxin was also detected in four samples of the 50-200 $\mu \mathrm{m}$ size-fraction, where $D$. acuminata was the only potentially toxic species detected.

Dinophysis acuminata was found less frequently during Expedition 2 (late summer), than for the previous expedition, being present in $\sim 38 \%$ of the net tow samples (Supplementary Table S2). In Niskin bottle samples, a single record of 20 cells $\mathrm{L}^{-1}$ was found in coastal waters from Valdés Peninsula $\left(\approx 43^{\circ} \mathrm{S}\right)$ (Fig. 4$)$. This species represented only an average of $8 \%$ of the cells of putatively toxigenic members of the genus; it was therefore not possible to estimate its relative contribution to the overall toxin content of the plankton.

On Expedition 3 (spring), Dinophysis acuminata appeared in $80 \%$ of net samples, representing an average of $98 \%$ of the cells of toxigenic Dinophysis species in the $20-50 \mu \mathrm{m}$ size-fraction. In Niskin bottle samples, D. acuminata was present in $52 \%$ of the samples, with cell densities ranging from 20 to 1680 cells $\mathrm{L}^{-1}$. The highest cell abundances were found at the continental shelf edge and in San Jorge Gulf (Fig. 4). From the 20-50 $\mu \mathrm{m}$ size-fraction, PTX-2 was detected at $41 \%$ of the stations (reaching the highest concentrations among the three sampling expeditions); PTX-11 was present at $23 \%$ of the stations, whereas OA was found only in a single instance (Supplementary Table S3). The highest concentrations of both PTX-2 and PTX-11 were found in the southern range (from $44^{\circ} \mathrm{S}$ to $46^{\circ} \mathrm{S}$ ) and in waters at or near the continental slope. The analog PTX-2sa was also detected, representing on average $8.6 \%$ and $23 \%$ of the total PTX-2 analogs in the $20-50$ and $50-200 \mu \mathrm{m}$ size-fractions, respectively. Dinophysis acuminata co-occurred in almost all samples with PTX-2 and PTX-11, except for some stations where $D$. acuminata cells were found but no toxins were detected. In contrast, for St 14 no toxigenic Dinophysis species were found but PTX-2 and PTX-11 were detected (Fig. 6). The calculated PTX-2 cell quota for $D$. acuminata varied between 0 and $22 \mathrm{pg} \mathrm{cell}^{-1}(n=14)$ and the maximum value was detected at St 36 , in waters near the slope adjacent to San Jorge Gulf $\left(46^{\circ} S\right)$. The second highest calculated value $\left(5.7 \mathrm{pg} \mathrm{cell}^{-1}\right)$ occurred at $40^{\circ} \mathrm{S}$, also within slope waters. Toxin cell quotas for PTX-11 ranged between 0.5 and $3.6 \mathrm{pg} \mathrm{cell}^{-1}(n=4)$, with the highest value found (as for PTX-2) at St 36. At the only station where OA was detected, $D$. acuminata cells were found and the toxin cell quota was estimated to be $0.5 \mathrm{pg} \mathrm{cell}^{-1}$.

\subsection{Dinophysis tripos distribution and related toxins}

On Expedition 1 (austral autumn), Dinophysis tripos was found in net samples at only three stations ( $6 \%$ of total sampled) between 


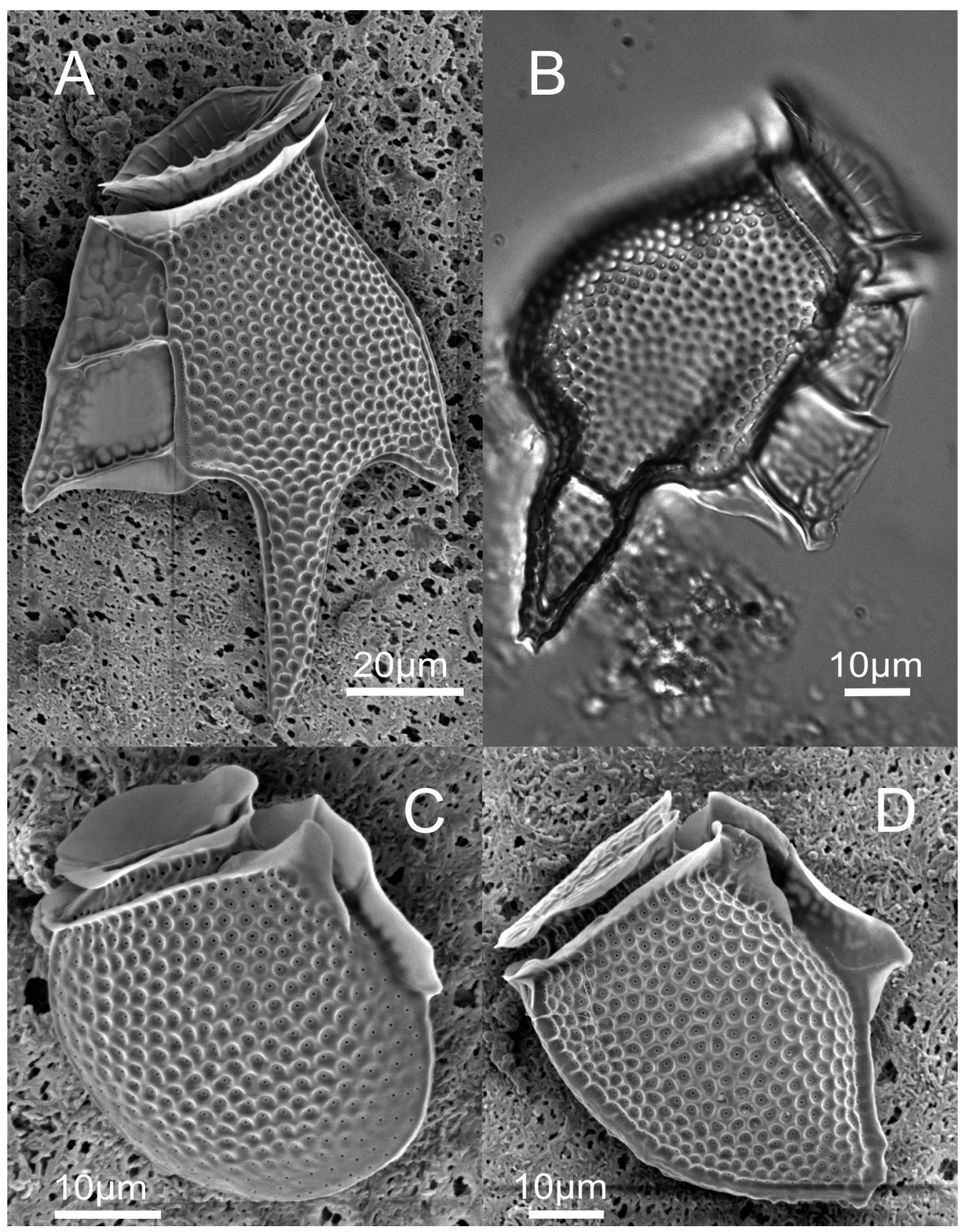

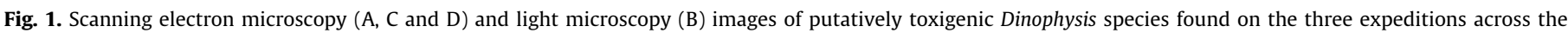
Argentine Sea. A: D. tripos; B: D. caudata; C: D. acuminata; D: D. norvegica.

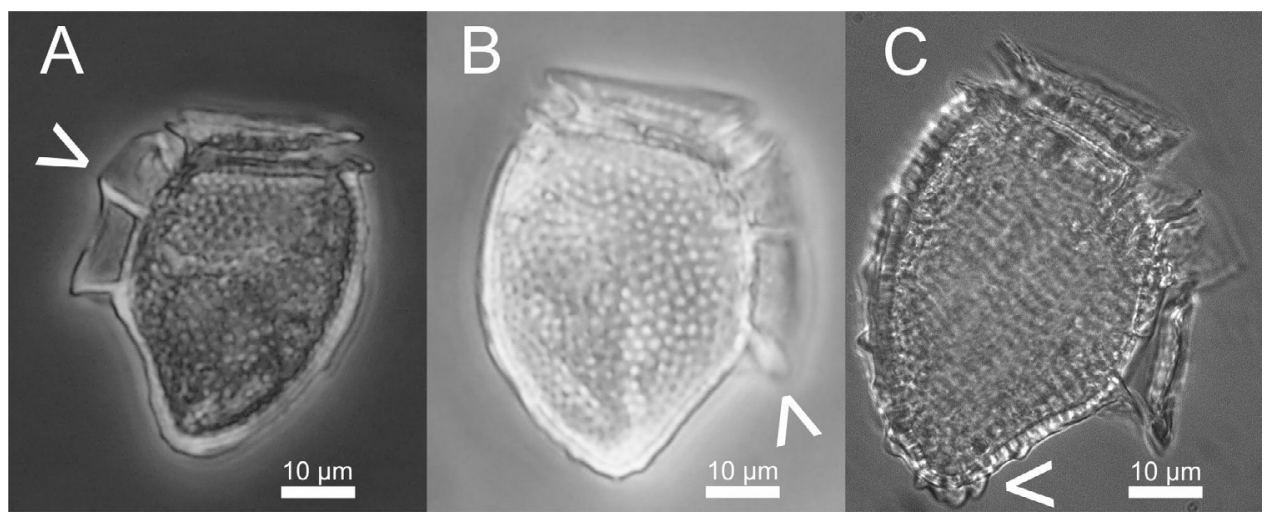

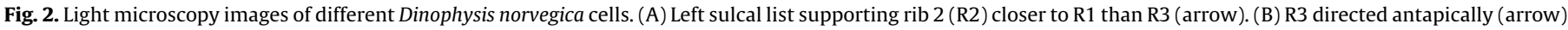
(C) Antapical knobs (arrow). 

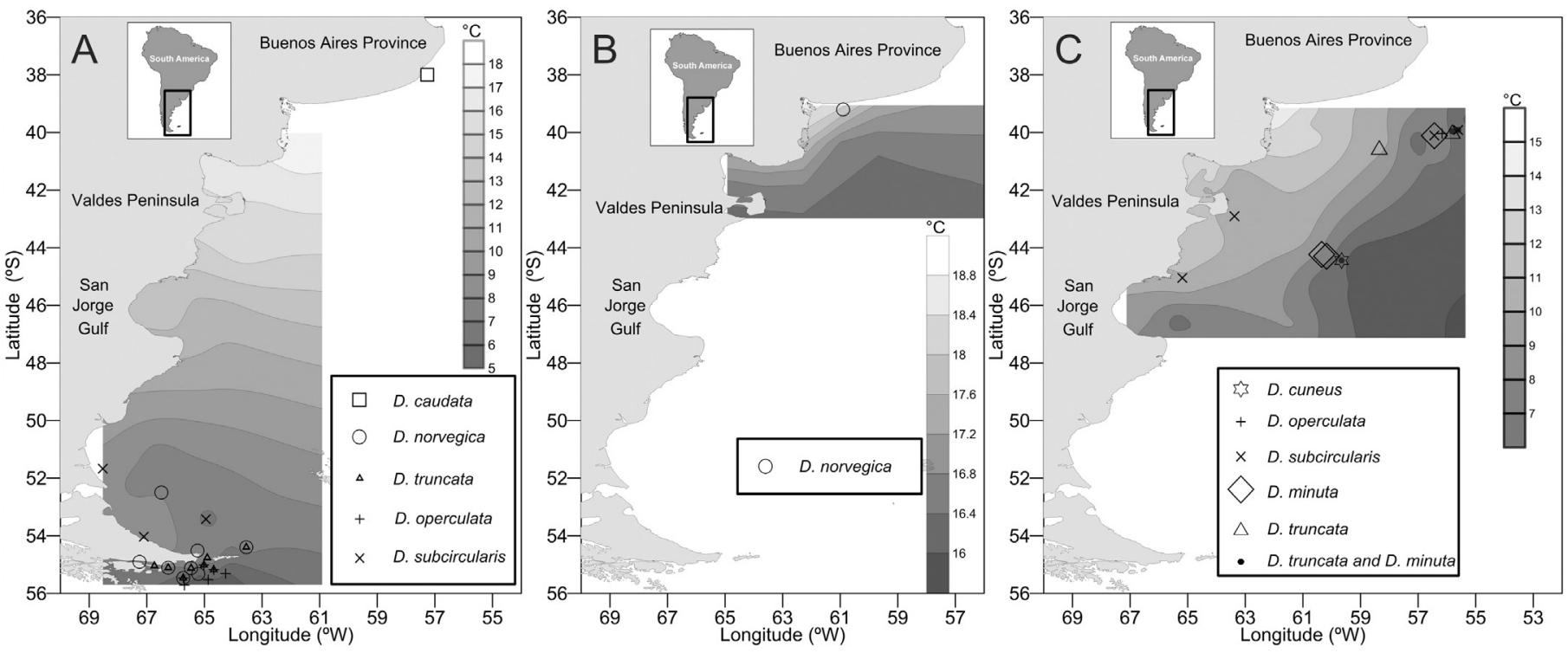

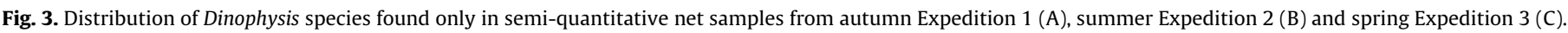

38 and $41^{\circ} \mathrm{S}$. In Niskin bottle samples, this species was detected only at St I50 and I51 (40 and $39^{\circ}$ S, respectively) and at low cell densities (Fig. 7). At St I50, D. tripos was the only toxigenic Dinophysis species found, occurring together with PTX-2 in the 50$200 \mu \mathrm{m}$ size-fraction. The estimated cell quota was $0.5 \mathrm{pg}$ cell $^{-1}$.

During Expedition 2 (late austral summer), Dinophysis tripos was the dominant species of the genus, averaging $70 \%$ of total Dinophysis cells in net tow samples where the genus was present. The species was found in $50 \%$ of the net samples, but occurred only within a geographically restricted area from $\approx 41$ to $43^{\circ} \mathrm{S}$

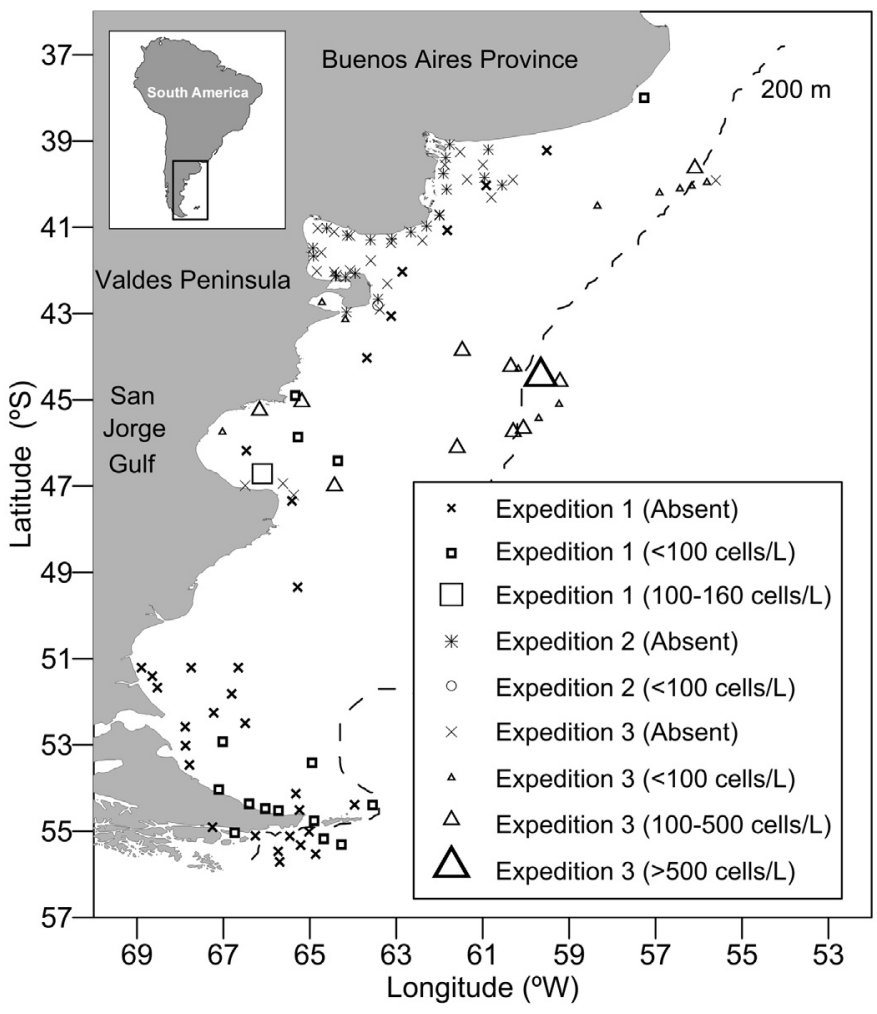

Fig. 4. Distribution and density of Dinophysis acuminata in Niskin bottle samples from the Argentine Sea during the three expeditions.
Dinophysis tripos was also present in $42 \%$ of the Niskin bottle samples at cell densities ranging from 20 to 1560 cells L $^{-1}$ (Fig. 7), with highest values at $41^{\circ} \mathrm{S}$. Pectenotoxin- 2 was present at $46 \%$ of the stations (from $\approx 41$ to $43^{\circ} \mathrm{S}$ ) within the $20-50 \mu \mathrm{m}$ size-fraction (Supplementary Table S2). Pectenotoxin-11 was detected in the smallest size-fraction at only one station. Small and/or intermediate $D$. tripos cells (sensu Rodríguez et al., 2012) with dorso-ventral cell dimensions ranging between 25 and $40 \mu \mathrm{m}$ were present in PTX-containing samples in the $20-50 \mu \mathrm{m}$ size-fraction (Fig. 8). The PTX-2 cell quotas estimated for $D$. tripos small/intermediate cells ranged between 0.1 and $0.9 \mathrm{pg}$ cell $^{-1}(n=3)$. On this expedition, the analog PTX-2sa accounted for $38 \%$ of the total PTX-2 analogs in the smallest size-fraction.

During Expedition 3 (austral spring), Dinophysis tripos was found in $14 \%$ of net samples, occurring in coastal waters from $41^{\circ} \mathrm{S}$ to $42^{\circ} \mathrm{S}$. In Niskin bottle samples, this species was present at $7 \%$ of the stations in low cell densities, ranging from 20 to 40 cells $\mathrm{L}^{-1}$ (Fig. 7). Dinophysis tripos was the only toxigenic species present together with PTX-2 and PTX-11 in sample 19 from the 50 to $200 \mu \mathrm{m}$ size-fraction.

\subsection{Distribution of other toxigenic Dinophysis species and Phalacroma rotundatum}

Among toxin-associated Dinophysis species other than Dinophysis acuminata and Dinophysis tripos, Dinophysis norvegica was perhaps the most significant. Nevertheless, $D$. norvegica was never present at high cell densities, as it was not detected in Niskin bottle samples in any season, and in net samples $2 \times 10^{3}$ cells NT ${ }^{-1}$ was the highest density detected. This species appeared in net samples from Expedition 1 (autumn) at 17\% of stations, all of them located southward of $52^{\circ} \mathrm{S}$ and from Expedition 2 (late summer) in only one sample at $39^{\circ} \mathrm{S}$. As shown in the distributional map (Fig. 3), it was not found during Expedition 3 (spring). In samples with detectable levels of toxins the species always co-occurred with $D$. acuminata.

Dinophysis caudata was only found during Expedition 1 (autumn) in one net sample at northern extent of the sampling area $\left(38^{\circ} \mathrm{S}\right)$ but where no toxins were detected. It was absent from quantitative samples (Fig. 3).

Phalacroma rotundatum was found at $11 \%$ of the stations from Expedition 1 (autumn). This species was mostly confined 

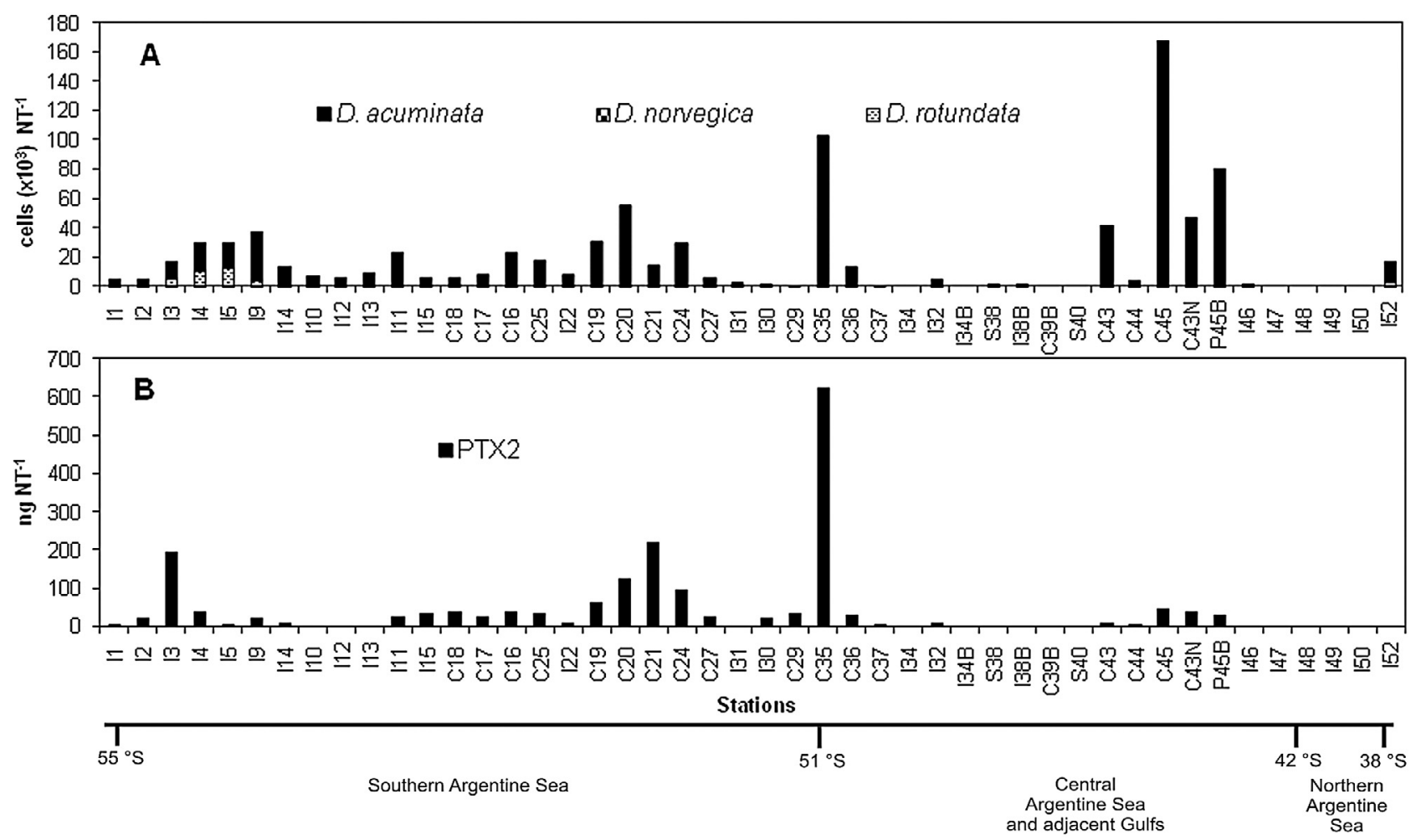

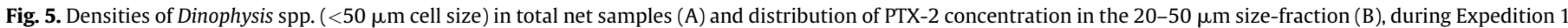
(autumn). No toxin data were available for stations I12 and I13.

to those samples collected around $55^{\circ} \mathrm{S}$, but it was also observed at one station at $38^{\circ} \mathrm{S}$. In spring (Expedition 3), P. rotundatum was present at $26 \%$ of the net sampled stations. This species did not appear in the quantitative samples of any expedition.
3.4. Environmental parameters related to distribution of Dinophysis spp.

Among all Dinophysis species found during the three expeditions, Dinophysis acuminata was represented over the widest
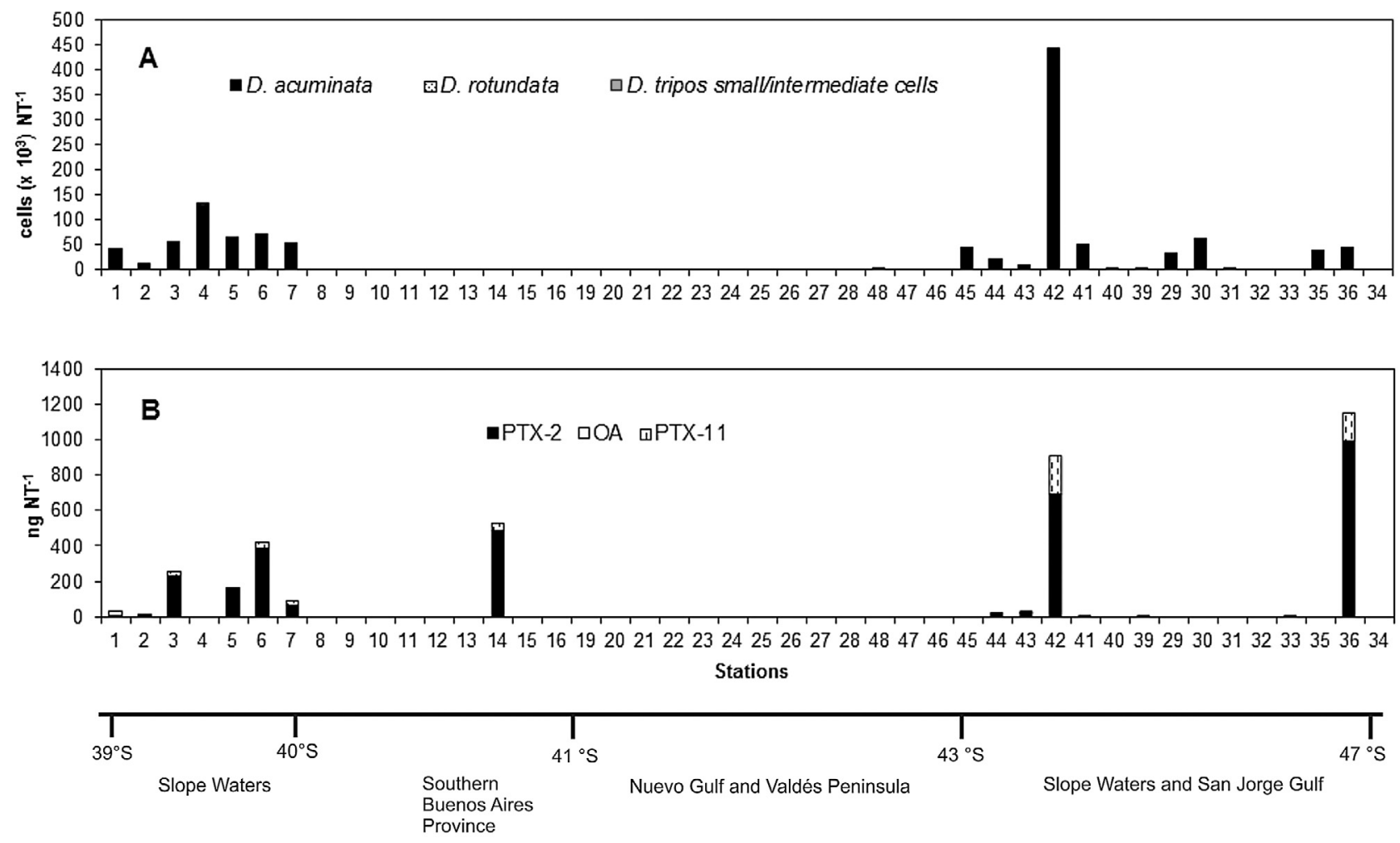

Fig. 6. Dinophysis spp. cell densities (A) and toxin concentrations (B) in the 20-50 $\mu \mathrm{m}$ size-fraction during Expedition 3 (spring). 


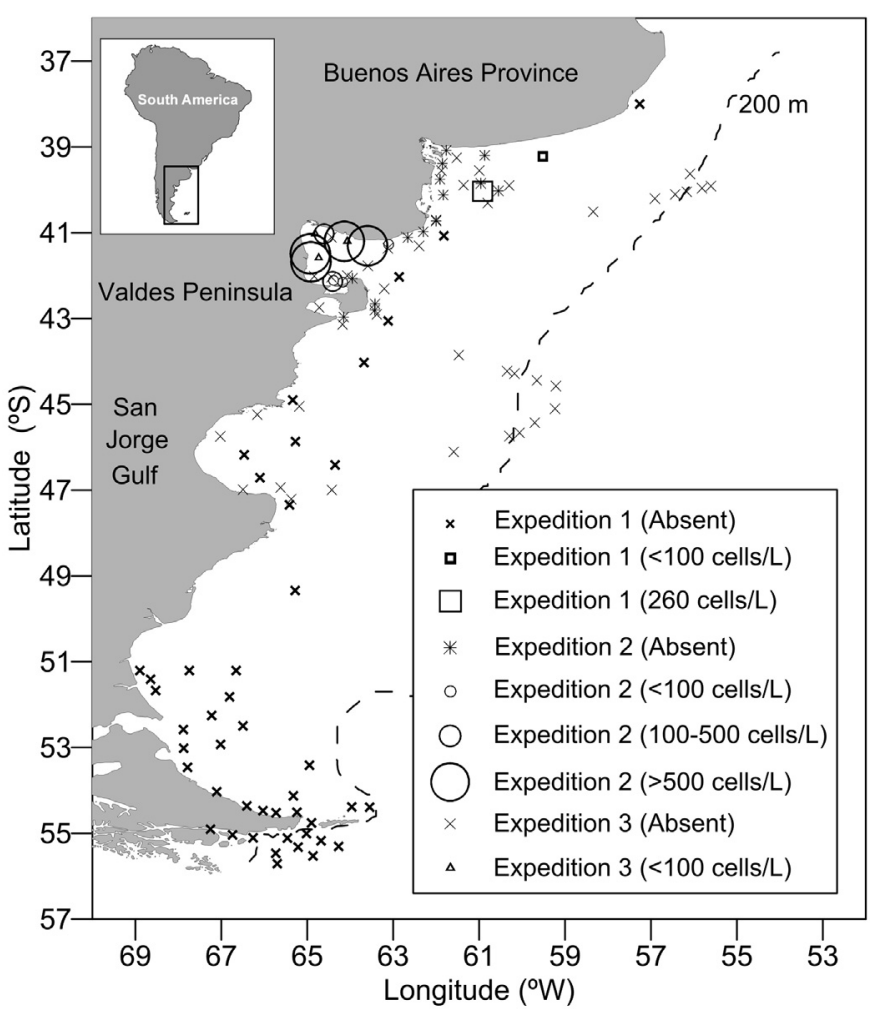

Fig. 7. Distribution and density of Dinophysis tripos in Niskin bottle samples from the Argentine Sea during the three expeditions.

temperature range $\left(5.7-18.4^{\circ} \mathrm{C}\right)$, although maximum cell densities in quantitative samples were found between $\sim 8$ and $\sim 13^{\circ} \mathrm{C}$. Dinophysis tripos was found only within temperate waters, at temperatures above $12{ }^{\circ} \mathrm{C}$, but yielded highest cell densities at $\sim 17^{\circ} \mathrm{C}$. The only record of Dinophysis caudata among the three expeditions was from waters at $18.8^{\circ} \mathrm{C}$. On the other hand, Dinophysis norvegica and Dinophysis operculata were both found in cooler waters, at temperatures $<9{ }^{\circ} \mathrm{C}$ (there is one record of $D$. norvegica at $18{ }^{\circ} \mathrm{C}$, but this corresponded only to one empty theca of the species). Dinophysis truncata, Dinophysis subcircularis and Phalacroma rotundatum were all detected in this study within similar temperature ranges from $\sim 6$ to $12^{\circ} \mathrm{C}$ (Table 1 ).

Dinophysis acuminata and Dinophysis norvegica were the two species found within the widest salinity range (31.2-34.2) among the three expeditions. All other Dinophysis species and Phalacroma rotundatum were present within a more limited salinity range ( 33 to 34 ) (Table 1$)$.

\section{Discussion}

Our results show that the genus Dinophysis is commonly found in the Argentine Sea throughout various seasons and over a wide geographical range. The most widely distributed species was Dinophysis acuminata, which is in accordance with previous reports (Balech, 1988; Sar et al., 2010; Negri et al., 2013; Sunesen et al., 2014). This species was the dominant taxon of the genus during Expeditions 1 and 3 (austral autumn and spring, respectively) and exhibited the highest cell densities at the southern extent of the sampling area, in slope waters and in the San Jorge Gulf, where surface temperatures ranged between $\sim 8$ and $\sim 13^{\circ} \mathrm{C}$. This distributional pattern coincides with the historical predominance of this species in sub-antarctic waters at temperatures lower than $14{ }^{\circ} \mathrm{C}$ (Balech, 1988). The higher cell densities found in the San Jorge Gulf may result from the specific hydrographic conditions present in this area, such as a strongly stratified water column known to favor dinoflagellate cell accumulations (Cloern et al., 2005; Jephson and Carlsson, 2009; Krock et al., 2015). The salinity range (33.2-33.9) in which the highest cell densities were detected corresponds to Argentine shelf waters, which consist mainly of subantarctic waters diluted by continental discharge (Piola and Falabella, 2009).
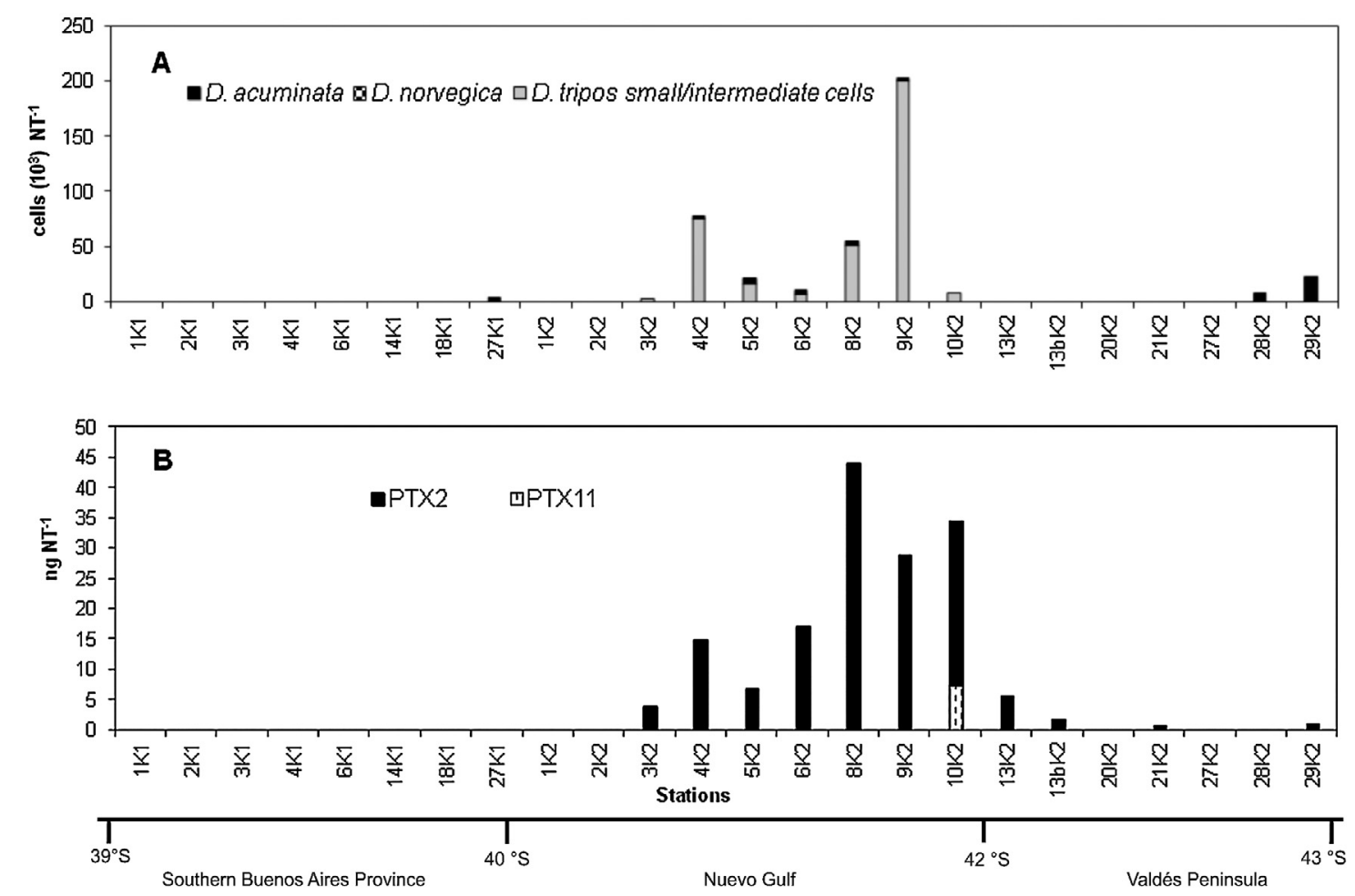

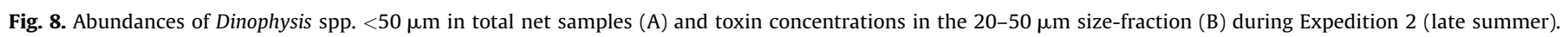


Table 1

Surface ( $2 \mathrm{~m}$ depth) temperature and salinity ranges in which Dinophysis spp. and Phalacroma rotundatum were found during the three expeditions.

\begin{tabular}{|c|c|c|c|c|c|c|c|c|c|c|}
\hline & D. acuminata & D. tripos & D. caudata & D. norvegica & D. truncata & D. subcircularis & D. operculata & D. minuta & D. cuneis & P. rotundatum \\
\hline \multicolumn{11}{|c|}{ Expedition 3 (spring) } \\
\hline$T\left({ }^{\circ} \mathrm{C}\right)$ & $7.4-14.8$ & $12.1-13.6$ & Not found & Not found & $7.8-11.4$ & $7.8-11.8$ & $8-8.3$ & $7.8-9.7$ & 8 & $7.4-11.4$ \\
\hline Salinity & $32.6-34.2$ & $33.9-34.1$ & Not found & Not found & $33.6-34$ & $33.1-34$ & 33.8 & $33.7-34$ & 33.8 & $33.6-34.2$ \\
\hline \multicolumn{11}{|c|}{ Expedition 2 (summer) } \\
\hline$T\left({ }^{\circ} \mathrm{C}\right)$ & $16.2-18.4$ & $14.4-17.9$ & Not found & 18.4 & Not found & Not found & Not found & Not found & Not found & Not found \\
\hline Salinity & 32.2 & no data & Not found & 32.2 & Not found & Not found & Not found & Not found & Not found & Not found \\
\hline \multicolumn{11}{|c|}{ Expedition 1 (autumn) } \\
\hline$T\left({ }^{\circ} \mathrm{C}\right)$ & $5.7-15.7$ & $17.3-17.7$ & 18.8 & $6-8.9$ & $6.8-8.4$ & $5.7-9.6$ & $5.8-7.8$ & Not found & Not found & $5.9-8.4$ \\
\hline Salinity & $31.2-34.2$ & 33.8 & 34.1 & $31.2-34.2$ & $33.2-34.2$ & $32.6-34.2$ & $33.6-34.2$ & Not found & Not found & $33.3-34.3$ \\
\hline \multicolumn{11}{|c|}{ All expeditions } \\
\hline$T\left({ }^{\circ} \mathrm{C}\right)$ & $5.7-18.4$ & $12.1-17.9$ & 18.8 & $6-8.9(18.4)$ & $6.8-11.4$ & $5.7-11.8$ & $5.8-8.3$ & $7.8-9.7$ & 8 & $5.9-11.4$ \\
\hline Salinity & $31.2-34.2$ & $33.8-34.1$ & 34.1 & $31.2-34.2$ & $33.2-34.2$ & $32.6-34.2$ & $33.6-34.2$ & $33.7-34$ & 33.8 & $33.3-34.3$ \\
\hline
\end{tabular}

In size-fractionated net samples, most Dinophysis acuminata cells were found in the $20-50 \mu \mathrm{m}$ size-fraction, although a small percentage were also detected in the $50-200 \mu \mathrm{m}$ fraction, likely as a result of partial net obstruction caused by high cell concentrations in the plankton concentrate. This may also explain the presence of PTX-2 in this larger size-fraction during the autumn expedition in samples where $D$. acuminata was the only Dinophysis species found. Nevertheless, transmission through the food web to heterotrophic species cannot be excluded as the proximal source of this toxin in the larger cell size-fraction. The presence of PTX has been detected in isolated cells of the heterotrophic dinoflagellates Protoperidinium divergens, Protoperidinium depressum, and Protoperidinium crassipes that were previously observed to feed on Dinophysis spp., suggesting that transfer of toxin to these heterotrophs had occurred (Miles et al., 2004).

Other food web toxin transfer vectors may also account for DST compartments in net tow or Niskin bottle size-fractions. Some copepod species (Oithona nana and Temora longicornis) can actively feed on toxic Dinophysis species, although the lack of correlation between abundance of this copepods and concentration of toxins led Maneiro et al. (2000) to suggest that transmission of DST by those species is not important. On the other hand, in the same work, these authors found that the tintinnid Favella serrata is able to accumulate DSP toxins when high cell density populations feed selectively on Dinophysis. Moreover, PTX might be released to seawater and remain attached to particulate matter and debris (Fux et al., 2011; Pizarro et al., 2008) that could be collected in the net tows. This non-living particulate component and/or the presence of vector microzooplankton and heterotrophic dinoflagellates can also lead to detection of toxins in samples where Dinophysis cells are no longer present, as in the case of St 14 (20$50 \mu \mathrm{m}$ size-fraction) from Expedition 3, and in samples from the larger size-fraction from Expedition 1 in autumn.

Lipophilic toxin analysis revealed a wide geographical distribution of PTX-2 associated with the presence of Dinophysis acuminata during both autumn (Expedition 1) and spring (Expedition 3). In addition, PTX-11 was also detected in association with $D$. acuminata during spring. The high variability (estimated from 0 to $22 \mathrm{pg} \mathrm{cell}^{-1}$ ) calculated for PTX-2 cell quotas in the present field study is in accordance with results from natural populations in Galician Rías, where toxin content of the same dinoflagellate species can vary considerably (Fernández et al., 2006). In this context, it is noteworthy that at three stations from Expedition 3, moderate $D$. acuminata cell concentrations were found in net samples $\left(41,47\right.$ and $131 \times 10^{3}$ cells NT $\left.{ }^{-1}\right)$, although no toxins were detected. This might imply the presence of nontoxigenic strains in natural populations of the species. Alternatively, cell disruption or even more minor physical stress may lead to toxin leakage from the plankton slurries collected on meshes during the filtration processes (Johansen and Rundberget, 2006). Plankton collection and filtration for toxin analyses during this study were carried out as rapidly as possible, and in the same manner for each sampling point, but some losses for the reasons mentioned cannot be ruled out (Pizarro et al., 2008) and could lead to underestimates of cell toxin quota.

Dinophysis tripos represented the second most important species in terms of cell densities among the three expeditions in the Argentine Sea. This species predominated during Expedition 2 (late summer) and its distribution was circumscribed to northward of about $\approx 42^{\circ}$ S. D. tripos was frequently found in San Matías Gulf, a semi-enclosed basin influenced by the Negro river (Guerrero and Piola, 1997), that is characterized by a high tidal energy (Tonini et al., 2007) and a vertical mixing (Palma et al., 2004). Moreover, multi-year records (2009-2011) from the Argentine Sea have reported this species throughout all seasons in the gulfs of northern Patagonia $\left(\approx 41-43^{\circ} \mathrm{S}\right)$, with the species appearing mainly during autumn and winter (Gracia Villalobos et al., 2015). Furthermore, maximum cell densities in this study were detected at $\sim 17{ }^{\circ} \mathrm{C}$, which agrees with known primary occurrence in tropical to temperate seas (Reguera et al., 2012). Co-occurrence of PTX-2 and PTX-11 in the smaller size-fraction (20-50 $\mu \mathrm{m})$ and small and intermediate $D$. tripos cells $(<50 \mu \mathrm{m})$ from Expedition 2 (late summer) agrees with results from our previous work, which showed a strong association of $D$. tripos large cells and occurrence of the same PTX in the 50-200 $\mu \mathrm{m}$ size-fraction (Fabro et al., 2015). This is further supported by comparison of the toxin profile of $D$. tripos from natural populations in the Gulf of San José and Nuevo Gulf, which was characterized by PTX-2 and PTX-11 (Gracia Villalobos et al., 2015).

The current finding of Dinophysis norvegica in the Argentine Sea is, as far as we know, the first record for the southwestern Atlantic Ocean. Considering the extensive work of Enrique Balech on dinoflagellates of the Argentine Sea and the southwest Atlantic (Balech, 1988), the fact that $D$. norvegica was never reported before from this area could indicate a recent introduction. It is also possible that this species may have been previously overlooked because even in our study, where it was found occasionally in net tow concentrates, cell densities were so low that it was never detected from Niskin bottle samples. Previous misidentification is unlikely, as $D$. norvegica can be easily distinguished from Dinophysis acuminata, primarily by the ventral rounded antapex of the latter species and also because in $D$. acuminata the most antapical rib of the sulcal list is not directed antapically, as is characteristic for $D$. norvegica. The latter species might be confused with Dinophysis acuta, which is known to occur in Chilean waters (Balech, 2002), but $D$. acuta is typically larger in size (54-100 $\mu \mathrm{m}$ ) and the maximum width is below the mid-line of the cell, which was never the case for the cells found in this study. 
Records of Dinophysis norvegica cells in this study were almost restricted to the southern and cooler waters, which agrees with its wide distribution in cold-temperate waters of the northern hemisphere, including the Baltic, Norwegian, North and Arctic Seas (Okolodkov and Dodge, 1996; Meyer-Harms and Pollenhe, 1998; Edvardsen et al., 2003; Jansen et al., 2006). Although $D$. norvegica is known to be frequently toxigenic around the world, our results do not allow a clear association between $D$. norvegica and particular lipophilic toxins, as this species was always found at lower cell densities than other putatively toxigenic species from the genus in samples that contained toxins.

The species Phalacroma rotundatum was found widely distributed in the Argentine Sea (from $39.6^{\circ} \mathrm{S}$ to $55^{\circ} \mathrm{S}$ ), although it was never detected at high cell densities. Even though $P$. rotundatum has never been unambiguously proven to produce toxins, it is important to have in mind that this species might act as a vector of toxins produced by mixotrophic co-occurring Dinophysis spp. (González-Gil et al., 2011).

Finally, Dinophysis caudata, a species typically distributed in tropical to warm temperate waters (Taylor, 1976), was confined to the north of the sampling area in the Argentine Sea. D. caudata is reported to be toxigenic, but in our study this species was rare and present in too low densities for any linkage to Dinophysis toxins.

Among Dinophysis species that have never been associated with toxic outbreaks (reviewed by Reguera et al., 2014 and references therein), five species ( $D$. truncata, $D$. operculata, $D$. cuneis, $D$. minuta and $D$. subcircularis) were found in our samples from Argentine waters. Nevertheless, as far as we know, these species have not been analyzed for toxin composition. Although $D$. truncata was the dominant species of the genus in Parsons Bay, Tasmania and cooccurred with detection of OA and DTX-1 in the blue mussel Mytilus edulis, Wallace (2011) concluded that it was unlikely that $D$. truncata was the cause of the low toxin levels found in the mussels. The DST concentrations were decreasing over time, despite periods of increasingly high $D$. truncata cell concentrations. This suggests that at least the Tasmanian strains of $D$. truncata are weakly toxic (if toxic at all).

The repeated observation of several different toxigenic Dinophysis species in the Argentine Sea and adjacent waters, but the almost total absence of OA and DTX, is particularly significant. In fact, among the three expeditions, comprising a total of 112 stations sampled during three different seasons (austral spring, late summer and autumn) and covering a wide geographical area (from $\approx 38-56^{\circ} \mathrm{S}$ ), toxigenic Dinophysis species were found at 91 stations, but OA was detected at just one station, and there only in trace concentrations. By contrast, pectenotoxins (PTX) were recorded in 67 samples, and showed a widespread distribution. This agrees with results from monitoring programs in the gulfs of north Patagonia, where PTX-2, PTX-11 and PTX-2sa were detected in plankton samples, but OA was absent (Gracia Villalobos et al., 2015).

A similar situation was observed from several populations from the south Pacific coast of Chile. Results of a study conducted along a transect of the Chilean coast showed a wide distribution of PTX in plankton over almost the entire transect, whereas OA was absent and DTX-1 was detected only within a narrow area at three sampling stations (Trefault et al., 2011). Likewise, DTX and OA were not detected in waters of northern Chile where Dinophysis acuminata was present, but PTX-2 and analogs were found (Krock et al., 2009). In Bahía Inglesa, Chile, no DTX or OA but high concentrations of PTX-2 (180 pg cell $\left.{ }^{-1}\right)$ were detected in $D$. acuminata cell isolates (Blanco et al., 2007). Moreover, neither OA nor DTX-1 was found in isolates of Dinophysis spp. from Reloncaví Estuary, Chile (Fux et al., 2011).

The predominance in the production of PTX over OA and its derivatives seems to be a recurrent pattern in some Dinophysis acuminata strains from other locations as well. Cell concentrates of this species from New Zealand yielded much more PTX than DTX (PTX/DTX ratio >22) (MacKenzie et al., 2005). A similar situation was observed among seven strains of $D$. acuminata from Denmark, which produced PTX-2, whereas none produced OA or DTX (Nielsen et al., 2012). Similarly, a D. acuminata culture isolated from Eel Pond, Woods Hole, Massachusetts, USA exposed to two different irradiance treatments (dark and light) showed a cellular PTX-2 content an order of magnitude greater than that of OA and DTX-1 in both treatments (Smith et al., 2012). On the other hand, strains that showed DST profiles dominated by OA and/or DTX have been found in western Europe (Moroño et al., 2003; Marcaillou et al., 2005), as is the case for D. acuminata cells from concentrated water samples from the Limfjord, Denmark (Jørgensen and Andersen, 2007).

The absence or only trace abundance of OA and DTX derivatives in samples from the three Argentine Sea expeditions cannot be attributed to low cell densities of Dinophysis species, because moderate to high densities of Dinophysis acuminata and Dinophysis tripos ( 1680 and 1560 cells $\mathrm{L}^{-1}$, respectively) were found in bottle samples and in fact were much higher in net tow samples.

In a recent study on the occurrence of lipophilic toxins in shellfish harvested along the Argentine Sea, toxins of the OA/DTX group were detected in 43 samples, whereas PTXs were detected in only 8 of a total of 69 samples examined (Turner and Goya, 2015). The authors found that PTX concentration was low and remarked upon the fact that 5 of the 8 samples with PTX did not contain OA. In addition, OA was commonly detected in shellfish collected in northern waters of the Argentine Sea $\left(\approx 36-38^{\circ} S\right)$. In our study, OA was also confined to the northern waters of the Argentine Sea but it was only rarely found in plankton samples. In this sense, the toxin composition in bivalve shellfish, such as mussels, tends to be different than in phytoplankton (Pavela-Vrančič et al., 2001; Moroño et al., 2003; Blanco et al., 2007; Alves-de-Souza et al., 2014). The proportion of toxins retained inside the producer cells versus excreted or leaked into seawater will affect not only relative concentration in seawater but also retention in shellfish. In the case of the PTX versus OA and DTX, the former group has a higher tendency to remain inside the dinoflagellate cell or remain strongly associated with cellular debris as a culture or natural bloom collapses (Nagai et al., 2011; Smith et al., 2012), which might lead to a higher proportion of PTXs toxins versus OA and DTX in plankton samples than in shellfish.

\section{Conclusions}

The genus Dinophysis showed a widespread distribution in the Argentine Sea and was mostly represented by Dinophysis acuminata; nevertheless, Dinophysis tripos was also commonly found and sometimes occurred in great cell densities. These two species appeared as the main species related to lipophilic toxins, primarily associated to PTX-2 and PTX-11. By contrast, Dinophysis caudata, Phalacroma rotundatum and Dinophysis norvegica were less commonly detected and at lower cell densities and thus no clear association to toxin distribution could be revealed.

Dinophysis species from Argentine coastal and shelf waters cooccurred primarily with PTX, as OA was rarely detected and at very low levels, whereas DTX was absent throughout the three expeditions. The general scarceness of OA and derivatives in our study might reflect a biogeographical tendency of Dinophysis populations from Argentine waters of the southwest Atlantic to produce primarily PTX as a result of a regionally specific combination of genetic and environmental factors. Hence more field and culture studies are required to elucidate the toxin profile of Dinophysis species and thus increase knowledge on the causative mechanisms of DSP outbreaks in this region. In any case, the 
distribution and abundance of Dinophysis and Phalacroma species detailed in this work, in addition to the lipophilic toxins detected together with the toxigenic species, provides a useful dataset to future monitoring programs and to predict association of specific dinoflagellates with the presence of lipophilic toxins in the Argentine Sea.

\section{Acknowledgements}

The authors thank Sebastian Göller for plankton sampling and processing during Expedition 2 and Wolfgang Drebing (AWI) for sample extraction and toxin measurements by LC-MS/MS. In addition, the friendly reception and support of the crew of the $R / V$ Puerto Deseado (CONICET-MINDEF, Argentina) in 2012 and of the $R /$ $V$ Bernardo Houssay (Prefectura Naval Argentina) in 2013 are gratefully acknowledged. This work was partially financed by the Helmholtz-Gemeinschaft Deutscher Forschungszentren through the research program PACES of the Alfred-Wegener-Institut, Helmholtz Zentrum für Polar- und Meeresforschung and the binational project MINCyT-BMBF (AL/11/03-ARG 11/021), and was supported by a PIP 0173 (CONICET) grant and by the European Commission under the 7th Framework Programme through the Action-IMCONet (FP7 IRSES, Action No. 319718). [SS]

\section{Appendix A. Supplementary data}

Supplementary data associated with this article can be found, in the online version, at doi:10.1016/j.hal.2016.09.001.

\section{References}

Alves-de-Souza, C., Varela, D., Contreras, C., de La Iglesia, P., Fernández, P., Hipp, B. Hernández, C., Riobó, P., Reguera, B., Franco, J.M., Diogène, J., García, C., Lagos, N., 2014. Seasonal variability of Dinophysis spp. and Protoceratium reticulatum associated to lipophilic shellfish toxins in a strongly stratified Chilean fjord. Deep-Sea Res. 2, Topical Stud. Oceanogr. 101, 152-162.

Balech, E., 1988. Los dinoflagelados del Atlántico Sudoccidental. Publicaciones Especiales. Instituto Español de Oceanografía, Madrid.

Balech, E., 2002. Dinoflagelados tecados tóxicos del cono sur americano. In: Sar, E.A Ferrario, M.E., Reguera, B. (Eds.), Floraciones Algales Nocivas en el Cono Sur Americano. Instituto Español Oceanográfico de Madrid, Vigo, pp. 125-144.

Blanco, J., Álvarez, G., Uribe, E., 2007. Identification of pectenotoxins in plankton, filter feeders, and isolated cells of a Dinophysis acuminata with an atypical toxin profile, from Chile. Toxicon 49, 710-716.

Ciminiello, P., Dell'Aversano, C., Fattorusso, E., Forino, M., Tartaglione, L., Boschetti, L., Rubini, S., Cangini, M., Pigozzi, S., Poletti, R., 2010. Complex toxin profile of Mytilus galloprovincialis from the Adriatic Sea revealed by LC-MS. Toxicon 55, 280-288.

Cloern, J.E., Schraga, T.S., Lopez, C.B., Knowles, N., Labiosa, R.G., Dugdale, R., 2005. Climate anomalies generate an exceptional dinoflagellate bloom in San Francisco Bay. Geophys. Res. Lett. 32, LI4608.

Edvardsen, B., Shalchian-Tabrizi, K., Jakobsen, K.S., Medlin, L.K., Dahl, E., Brubak, S. Paasche, E., 2003. Genetic variability and molecular phylogeny of Dinophysis species (Dinophyceae) from Norwegian waters inferred from single cell analyses of rDNA. J. Phycol. 39, 395-408.

Fabro, E., Almandoz, G.O., Ferrario, M.E., Hoffmeyer, M.S., Pettigrosso, R.E., Uibrig, R., Krock, B., 2015. Co-occurrence of Dinophysis tripos and pectenotoxins in Argentinean shelf waters. Harmful Algae 42, 25-33.

Fernández, M.L., Reguera, B., González-Gil, S., Míguez, A., 2006. Pectenotoxin-2 in single-cell isolates of Dinophysis caudata and Dinophysis acuta from the Galícian Rias (NW Spain). Toxicon 48, 477-490.

Fux, E., Smith, J.L., Tong, M., Guzmán, L., Anderson, D.M., 2011. Toxin profiles of five geographical isolates of Dinophysis spp. from North and South America. Toxicon 57, 275-287.

Gayoso, A.M., Dover, S., Morton, S., Busman, M., Moeller, P., Fulco, V.K., Maranda, L., 2002. Diarrhetic shellfish poisoning associated with Prorocentrum lima (Dinophyceae) in Patagonian Gulfs (Argentina). J. Shellfish Res. 21, 461-463.

González-Gil, S., Pizarro, G., Paz, B., Velo-Suárez, L., Reguera, B., 2011. Considerations on the toxigenic nature and prey sources of Phalacroma rotundatum. Aquat. Microb. Ecol. 64, 197-203.

Gracia Villalobos, L., Santinelli, N., Sastre, V., Krock, B., Esteves, J.L., 2015. Dinophysis species associated with Diarrhetic Shellfish Poisoning (DSP) episodes in North Patagonian gulfs (Chubut, Argentina). J. Shellfish Res. 34, 1141-1149.

Guerrero, R.A., Piola, A.R., 1997. Masas de agua en la plataforma continental. In: Boschi, E. (Ed.), El Mar Argentino y sus Recursos Pesquero, Tomo I: Antecedentes históricos de las exploraciones en el mar y las características ambientales.
Instituto Nacional de Investigación y Desarrollo Pesquero, Mar del Plata, Argentina, pp. 107-119.

ICES, 2006. Report on the ICES/IOC workshop on new and classic techniques for the determination of numerical abundance and biovolume of HAB species - evaluation of the cost, time-efficiency and intercalibration methods (WKNCT), 22-27 August 2005, Kristineberg, Sweden. ICES CM 2005/C:10.

Jensen, M.A., Daugbjerg, N., 2009. Molecular phylogeny of selected species of the order Dinophysiales (Dinophyceae) - testing the hypothesis of a Dinophysioid radiation. J. Phycol. 45 (5), 1136-1152.

Jansen, S., Riser, C.W., Wassmann, P., Bathmann, U., 2006. Copepod feeding behaviour and egg production during a dinoflagellate bloom in the North Sea. Harmful Algae 5, 102-112.

Jephson, T., Carlsson, P., 2009. Species and stratification dependent diel vertical migration behaviour of three dinoflagellate species in a laboratory study. J. Plankton Res. 31, 1353-1362.

Johansen, M., Rundberget, T., 2006. The sampling technique greatly affects the toxin content in Dinophysis spp. cells.In: Programme and Abstracts of the XII International Conference on Harmful Algae. Copenhagen, p. 200, Available at: www bi.ku.dk/hab/docs/P\&A_Book.pdf.

Jørgensen, K., Andersen, P., 2007. Relation between the concentration of Dinophysis acuminata and Diarrheic Shellfish Poisoning toxins in blue mussels (Mytilus edulis) during a toxic episode in the Limfjord (Denmark). J. Shellfish Res. 26 1081-1087.

Kamiyama, T., Nagai, S., Suzuki, T., Miyamura, K., 2010. Effect of temperature on production of okadaic acid, dinophysistoxin-1, and pectenotoxin-2 by Dinophysis acuminata in culture experiments. Aquat. Microb. Ecol. 60, 193-202.

Kim, S., Kang, Y.G., Kim, Y.G., Yih, W., Coats, D.W., Park, M.G., 2008. Growth and grazing responses of the mixotrophic dinoflagellate Dinophysis acuminata as functions of light intensity and prey concentration. Aquat. Microb. Ecol. 51, 301-310.

Korringa, P., Roskam, R.T., 1961. An Unusual Case of Mussel Poisoning. C.M./ Shellfish Committee, International Council for the Exploration of the Sea, Copenhagen, Denmark, pp. 2.

Krock, B., Tillmann, U., John, U., Cembella, A.D., 2008. LC-MS/MS on board ship tandem mass spectrometry in the search for phycotoxins and novel toxigenic plankton from the North Sea. Anal. Bioanal. Chem. 392, 797-803.

Krock, B., Seguel, C.G., Valderrama, K., Tillmann, U., 2009. Pectenotoxins and yessotoxin from Arica Bay, north Chile as determined by tandem mass spectrometry. Toxicon 54, 364-367.

Krock, B., Borel, C.M., Barrera, F., Tillmann, U., Fabro, E., Almandoz, G.O., Ferrario, M., Garzón Cardona, J.E., Koch, B.P., Alonso, C., Lara, R., 2015. Analysis of the hydrographic conditions and cyst beds in the San Jorge Gulf, Argentina, that favor dinoflagellate population development including toxigenic species and their toxins. J. Marine Syst. 148, 86-100.

Lee, J.S., Igarashi, T., Fraga, S., Dahl, E., Hovgaard, P., 1989. Determination of diarrhetic shellfish toxins in various dinoflagellate species. J. Appl. Phycol. 1 $147-152$.

LeGresley, M., McDermott, G., 2010. Counting chamber methods for quantitative phytoplankton analysis - haemocytometer, Palmer-Maloney cell and Sedgewick-Rafter cell. In: Karlson, B., Cusack, C., Bresnan, E. (Eds.), Microscopic and Molecular Methods for Quantitative Phytoplankton Analysis. UNESCO, Paris, pp. 25-30.

MacKenzie, L., Beuzenberg, V., Holland, P., McNabb, P., Suzuki, T., Selwood, A., 2005 Pectenotoxin and okadaic acid-based toxin profiles in Dinophysis acuta and Dinophysis acuminata from New Zealand. Harmful Algae 4, 75-85.

Maneiro, I., Frangópulos, M., Guisande, C., Fernández, M., Reguera, B., Riveiro, I., 2000. Zooplankton as a potential vector of diarrhetic shellfish poisoning toxins through the food web. Mar. Ecol. Prog. Ser. 201, 155-163.

Marcaillou, C., Mondeguer, F., Gentien, P., 2005. Contribution to toxicity assessment of Dinophysis acuminata (Dinophyceae). J. Appl. Phycol. 17, 155-160.

Meyer-Harms, B., Pollenhe, F., 1998. Alloxanthin in Dinophysis norvegica (Dinophysiales, Dinophyceae) from the Baltic Sea. J. Phycol. 34, 280-285.

Miles, C.O., Wilkins, A.L., Samdal, I.A., Sandvik, M., Petersen, D., Quilliam, M.A. Nausvoll, L.J., Rundberget, T., Torgersen, T., Hovgaard, P., Jensen, D.J., Cooney, J.M., 2004. A novel pectenotoxin, PTX-12, in Dinophysis spp. and shellfish from Norway. Chem. Res. Toxicol. 17 (11), 1423-1433.

Montoya, N.G., Carignan, M.O., Benavides, H.O., 2013. Toxinas emergentes en el Mar Argentino. In: Reunião Latino-americana sobre Algas Nocivas, Florianópolis, Brasil, p. 12.

Moroño, A., Arévalo, F., Fernández, M.L., Maneiro, J., Pazos, Y., Salgado, C., Blanco, J., 2003. Accumulation and transformation of DSP toxins in mussels Mytilus galloprovincialis during a toxic episode caused by Dinophysis acuminata. Aquat. Toxicol. 62, 269-280.

Murata, M., Shimatani, M., Sugitani, H., Oshima, Y., Yasumoto, T., 1982. Isolation and structural elucidation of the causative toxin of diarrhetic shellfish poisoning Bull. Jpn. Soc. Sci. Fish. 48, 549-552.

Nagai, S., Suzuki, T., Nishikawa, T., Kamiyama, T., 2011. Differences in the production and excretion kinetics of okadaic acid, dinophysistoxin-1, and pectenotoxin-2 between cultures of Dinophysis acuminata and Dinophysis fortii isolated from Western Japan. J. Phycol. 47, 1326-1337.

Negri, R.M., Silva, R.I., Segura, V., Cucchi Colleoni, A.D., 2013. Estructura de la comunidad del fitoplancton en el área de El Rincón, Mar Argentino (febrero 2011). Rev. Invest. Desarr. Pesq. 23, 7-22.

Nielsen, L.T., Krock, B., Hansen, P.J., 2012. Effects of light and food availability on toxin production, growth and photosynthesis in Dinophysis acuminata. Mar. Ecol. Prog. Ser. 471, 37-51. 
Okolodkov, Y.B., Dodge, J.D., 1996. Biodiversity and biogeography of planktonic dinoflagellates in the Arctic Ocean. J. Exp. Mar. Biol. Ecol. 202, 19-27.

Palma, E.D., Matano, R.P., Piola, A.R., 2004. A numerical study of the South Western Atlantic Shelf circulation: barotropic response to tidal and wind forcing. J. Geophys. Res. 109, C08014, http://dx.doi.org/10.1029/2004JC002315.

Pavela-Vrančič, M., Meštrović, V., Marasović, I., Gillman, M., Furey, A., James, K.K. 2001. The occurrence of 7-epi-pectenotoxin-2 seco acid in the coastal waters of the central Adriatic (Kastela Bay). Toxicon 39, 771-779.

Piola, A.R., Falabella, V., 2009. El mar Patagónico. In: Falabella, V., Campagna, C., Croxall, J. (Eds.), El Mar Patagónico: Especies y Espacios. Wildlife Conservation Society e Birdlife International, Cambridge, pp. 56-75.

Pizarro, G., Escalera, L., González-Gil, S., Franco, J.M., Reguera, B., 2008. Growth behaviour and cell toxin quota of Dinophysis acuta during a daily cycle. Mar. Ecol. Prog. Ser. 353, 89-105.

Quilliam, M.A., Ross, N.W., 1996. Analysis of diarrhetic shellfish poisoning toxins and metabolites in plankton and shellfish by ion-spray liquid chromatographymass spectrometry. In: Snyder, A.P. (Ed.), Biochemical and Biotechnological Applications of Electrospray Ionization Mass Spectrometry. American Chemical Society, Washington, DC, pp. 351-364.

Reguera, B., Pizarro, G., 2008. Planktonic dinoflagellates that contain polyether toxins of the old "DSP complex". In: Botana, L.M. (Ed.), Seafood and Freshwater Toxins. Pharmacology, Physiology, and Detection. CRC Press, Boca Raton, pp. 257-284.

Reguera, B., Velo-Suárez, L., Raine, R., Park, M.G., 2012. Harmful Dinophysis species: a review. Harmful Algae 14, 87-106.

Reguera, B., Riobó, P., Rodríguez, F., Díaz, P.A., Pizarro, G., Paz, B., Franco, J.M., Blanco, J., 2014. Dinophysis toxins: causative organisms, distribution and fate in shellfish. Mar. Drugs 12, 394-461.

Rodríguez, F., Escalera, L., Reguera, B., Rial, P., Riobó, P., Silva, T.J., 2012. Morphological variability, toxinology and genetics of the dinoflagellate Dinophysis tripos (Dinophysiaceae, Dinophysiales). Harmful Algae 13, 26-33.

Sar, E.A., Sunesen, I., Lavigne, A.S., Goya, A.B., 2010. Dinophysis spp. asociadas a detección de toxinas diarreicas en moluscos (DSTs) y a intoxicación diarreica en humanos (Provincia de Buenos Aires, Argentina). Rev. Biol. Mar. Oceanogr. 45 451-460.

Sar, E.A., Sunesen, I., Goya, A.B., Lavigne, A.S., Tapias, E., García, C., Lagos, N., 2012. First report of diarrheic shellfish toxins in mollusks from Buenos Aires Province (Argentina) associated with Dinophysis spp.: evidence of okadaic acid, dinophysistoxin-1 and their acyl derivatives. Bol. Soc. Argent. Bot. 47, 5-14.
Smith, J.L., Tong, M., Fux, E., Anderson, D.M., 2012. Toxin production, retention, and extracellular release by Dinophysis acuminata during extended stationary phase and culture decline. Harmful Algae 19, 125-132.

Sunesen, I., Lavigne, A., Goya, A., Sar, E.A., 2014. Episodios de toxicidad en moluscos de aguas marinas costeras de la Provincia de Buenos Aires (Argentina) asociados a algas toxígenas (marzo de 2008-marzo de 2013). Bol. Soc. Argent. Bot. 49, 327-339.

Suzuki, T., Mitsuya, T., Matsubara, H., Yamasaki, M., 1998. Determination of pectenotoxin-2 after solid-phase extraction from seawater and from the dinoflagellate Dinophysis fortii by liquid chromatography with electrospray mass spectrometry and ultraviolet detection. Evidence of oxidation of pectenotoxin-2 to pectenotoxin-6 in scallops. J. Chromatogr. A 815, 155-160.

Taylor, F.J.R., 1976. Dinoflagellates from the International Indian Ocean Expedition: A Report of the Material Collected by the R.V. Anton Bruun 1963-1964. Bibliotheca Botanica 132, Stuttgart, Germany.

Terao, K., Ito, E., Yanagi, T., Yasumoto, T., 1986. Histopathological studies on experimental marine toxin poisoning. I. Ultrastructural changes in the small intestine and liver of suckling mice induced by dinophysistoxin-1 and pectenotoxin-1. Toxicon 24, 1141-1151.

Tonini, M., Palma, E.D., Rivas, A.L., 2007. Simulación numérica de la circulación y Frentes Térmicos en los golfos Norpatagónicos. Mecánica Computacional 26, 3757-3768.

Trefault, N., Krock, B., Delherbe, N., Cembella, A., Vásquez, M., 2011. Latitudinal transects in the southeastern Pacific Ocean reveal a diverse but patchy distribution of phycotoxins. Toxicon 58, 389-397.

Turner, A.D., Goya, A.B., 2015. Occurrence and profiles of lipophilic toxins in shellfish harvested from Argentina. Toxicon 102, 32-42.

Utermöhl, H., 1958. Zur Vervollkommnung der quantitativen Phytoplankton Methodik. Mitt. Int. Ver. Theor. Angew. Limnol. 9, 1-38.

Wallace, G.M., June 2011. Diarrhetic shellfish toxins in Tasmanian coastal waters: causative dinoflagellate organisms, dissolved toxins and shellfish depuration. (Ph.D. Thesis)University of Tasmania, Hobart, Tasmania.

Yasumoto, T., Oshima, Y., Yamaguchi, M., 1978. Bull. Jpn. Soc. Sci. Fish. 44, 1249.

Yasumoto, T., Sugawara, W., Fukuyo, Y., Oguri, H., Igarashi, T., Fujita, N., 1980. Identification of Dinophysis fortii as the causative organism of diarrhetic shellfish poisoning in the Tohoku district. Bull. Jpn. Soc. Sci. Fish. 46, 1405-1411.

Zingone, A., Larsen, J., 2014. DinophysialesIn: IOC-UNESCO Taxonomic Reference List of Harmful Micro Algae. Available at http://www.marinespecies.org/HAB (accessed 20.03.2014). 